cholinergic marker enzymes. Neurosci Lett 1982;28:217-22.

${ }^{8}$ Henke $H$, Lang W. Cholinergic enzymes in neocortex, hippocampus and basal forebrain of non-neurological and senile dementia of Alzheimer-type patients. Brain Res 1983; 267: 281-91.

' White P, Hiley CR, Goodhart MJ, et al. Neocortical cholinergic neurons in elderly people. Lancet 1977;i:668-71.

${ }^{10}$ Davies P, Verth AH. Regional distribution of muscarinic acetylcholine receptors in normal and Alzheimer's type dementia brains. Brain Res 1978;138:385-92.

"Bowen DM, Spillane JA, Curzon G, et al. Accelerated ageing or selective neuronal loss as an important cause of dementia? Lancet 1979;i:11-14.

${ }^{12}$ Reisine TD, Yamamura HI, Bird ED, Spokes E, Enna SJ. Pre- and post-synaptic neurochemical alterations in Alzheimer's disease, Brain Res 1978;159:477-80.

${ }^{13}$ Reisine TD, Fields JZ, Yamamura HI, et al. Neurotransmitter receptor alterations in Parkinson's disease. Life Sci 1977;21:33544.

${ }^{14}$ Rinne UK, Koskinen V, Lönnberg P. Neurotransmitter receptors in the parkinsonian brain. In: Rinne UK, Klingler M, Stamm G, eds. Parkinson's Disease-Current Progress, Problems and Management. Amsterdam: Elsevier, 1980:93-107.

is Drachman DA, Leavitt J. Human memory and the cholinergic system. A relationship to ageing. Arch Neurol 1974;30:113-21.

${ }^{16}$ Mishkin M. Memory in monkeys severely impaired by combined but not by separate removal of amygdala and hippocampus. Nature 1978;273:297-8.

Accepted 16 December 1983

\section{Metastatic carcinoid tumour compressing the cauda equina}

Sir: We report a patient with a progressive syndrome of cauda equina compression due to an osteogenic metastasis from an intestinal carcinoid tumour.

A 64-year-old female presented with a one year history of low back pain irradiating to both legs for three months. Prolonged sitting caused numbness in both thighs. Six months before she had been examined for these complaints at another hospital, and radiographs of the lumbar spine were reported normal. She had a ten year history of abdominal pain and intermittent diarrhoea and two years previously had presented with acute intestinal obstruction. A small bowel carcinoid was removed at operation. There were multiple metastases to the mesentery and abdominal lymph nodes. Physical examination showed bilateral grade 4 quadriceps weakness; the knee and ankle jerks on the right side were reduced. Straight leg raising was normal on both sides but there was bilateral femoral nerve stretch pain. Cauda equina compression at the L3 level was presumed. Plain radiographs of the lumbar spine showed sclerosis of the body and the right pedicle of L3. Metrizamide myelography demonstrated a complete block at L3. CSF analysis including a smear of the sediment was unremarkable. At surgery a highly vascular tumour was found in the epidural space opposite L3. The tumour was clearly defined and did not seem to arise from bone, but a biopsy of the vertebral arch and body demonstrated carcinoid tissue in the spongiosa. The lumbar spine was irradiated with 6000 rads. Signs and symptoms disappeared and the patient remained well for 12 months. Postoperatively she complained of periods of flushing which reacted well to methysergide. She died 15 months later following multiple abdominal complications included intestinal obstructions.

Although carcinoid tumours were initially considered as non-infiltrating and non-metastasing, ${ }^{1}$ subsequent case reports illustrated that carcinoid tumours may metastasise to the lymph nodes, ${ }^{23}$ and very rarely to the nervous system. ${ }^{45}$ To our knowledge only one well-documented case of cervical spinal cord compression has been published, ${ }^{6}$ and no cases with lumbar involvement producing cauda compression could be traced. When our patient presented with low back pain and inconstant radicular symptoms, the presence of degenerative bone disease or disc pathology was much more probable $e^{7-9}$ than metastatic carcinoid tumour. Plain radiographs of the spine six months previously were normal but at a later stage there were discrete abnormalities on plain radiographs of the lumbar spine. As osteoblastic metastases are well recognised complications of malignant carcinoid tumours, further examinations were performed and showed a metastasis at $\mathrm{L} 3$. This seems a very rare complication of carcinoid tumour. A neurofibroma had also to be excluded, because the combination of carcinoid and von Recklinghausen's neurofibromatosis had been stressed in two previous reports. ${ }^{1011}$

In conclusion, the patient illustrates that in presence of persisting spinal pain, radiculopathy or myelopathy, a vertebral metastasis should be considered even when the primary tumour is of carcinoid origin. As in the case of other bone metastases a bone isotope scan has to be performed even when plain films of the spine are nor- mal $^{12}$ while also an immuno-assay techni- 으 que with specific antibodies to serotonin $Z$ may be a very sensitive method of carcinoid metastasis detection. ${ }^{13}$ These procedures may detect the lesion earlier, resulting in temporary pain relief by röntgen $\overline{\widehat{Q}}$ iradiation. Our patient remained pain free for one year.

BJJ ANSINK HCE VAN LAMBALGEN Department of Neurology G DAVIES $\Rightarrow$ Department of Neuroradiology, $\stackrel{\vec{P}}{\rightarrow}$ Sint Lucas Ziekenhuis, 음 Jan Tooropstraat 164, 등 1061 AE AMSTERDAM, The Netherlands

\section{References}

1 Oberndorfer SS. Karzinoide Tumor des Dünndarms Frankfurter Zeits Pathologie $\vec{\circ}$ 1907;1:426-37.

${ }^{2}$ Gosset A, Masson P. Tumeurs carcinoides et $\vec{\omega}$ métastases mésentériaux. Press Méd 1914;22:237-9.

${ }^{3}$ Paevy PW, Rogers JV, Clement JL, Burns JB. Unusual osteoblastic metastases from carcinoid tumors. Radiology 1973;107:327-30.

4 Wagner PK. Magenkarzinoid mit Hirnmetą कं tase. Med Klin 1979;74:1439-43.

5 Fishman ML, Rosenthal S. Optic nerve metro tasis from a mediastinal carcinoid tumo Br J Ophthalmol 1976;60:583-8.

- Manoli RS, Bartelemy CR. Osteolytic and osteoblastic metastases due to carcingid $\subseteq$ tumors. $\mathrm{Cl} \mathrm{Nucl} \mathrm{Med} \mathrm{1980;5:102-5.}$

7 Gathier JC. Radicular disorders due to lumbin discopathy. In: Vinken PJ, Bruyn GW ees. $\overrightarrow{0}$ Handbook of Clinical Neurology, vol. 27 573-604. Amersterdam: North Holland, 1976.

${ }^{8}$ Guidetti B, Fortuna A. Differential diagnosis of intramedullary and extramedullary tumours. In: Vinken PJ, Bruyn GW eds. Handbook of Clinical Neurology, vol. 19:ฉ 51-75. Amsterdam: North Holland, 1975. \

${ }^{9}$ Levitt P, Ranshoff J, Speilholz N. The differential diagnosis of tumors in the conus medullaris and cauda equina. In: Vinken PJ, Bruyn 3 GW eds. Handbook of Clinical Neurology, $\overline{7}$ vol. 19: 77-90. Amsterdam: North Holland, 1975.

${ }^{10}$ Trouillas P, Robert JM. Maladie de Recklinghausen et phacomatoses de dysplasie néoplasiantes frappant le systéme APUD. Nouv: Press Med 1974;3:2399-401.

"Alamowitch Ch, Larousse C. Association de la. maladie de Recklinghausen et carcinoide deO l'ampoule de Vater. Nouv Press. Med 1982;11:3255-7.

${ }_{12}$ Toomey B, Felson B. Osteoblastic bone metas-극 tases in gastrointestinal and bronchial car- $D$ cinoids. Am Roentgen Ray Soc (Cincinnati, Ohio) 1959;22-5.

${ }^{13}$ Cuello AC. Serotonin immunoreactivity in car- $N$ cinoid tumours demonstrated by a monoclonal antibody. Lancet 1982;I:771-83.

Accepted 22 December 1983 